\title{
The Disappeared as a Transnational Figure or How to Deal with the Vain Yesterday
}

\author{
SILVANA MANDOLESSI* and MARIANA EVA PEREZ** \\ *Universität Konstanz, 78457, Konstanz, Germany; and KU Leuven, Blijde- \\ Inkomststraat 21, 3000 Leuven, Belgium. E-mail: Silvana.Mandolessi@arts. \\ kuleuven.be \\ **Universität Konstanz, 78457, Konstanz, Germany. E-mail: Mariana.Perez@ \\ uni-konstanz.de
}

This article examines the figure of the desaparecido as a transnational symbol, focusing on the 'success' this figure has had in the contemporary debate about memory in Spain. Taken from the repressive context of the dictatorships of the 1970s in South America, the disappeared have travelled to the Spain of the twenty-first century, where they are progressively replacing the former 'fusilados y paseados' of the Franco Regime. After charting the ways in which the term has been used in the public debate, we analyse the figure of the disappeared in the novel, El vano ayer, by the Spanish writer Isaac Rosa.

'My grandfather was also a desaparecido' is the title of an article published in a newspaper in 2000. It is Emilio Silva, grandson of a fusilado (one who has been shot) in the Spanish Civil War, who makes this statement. The article, published in La crónica de León ${ }^{1}$ tells of how Silva decided to find the remains of his grandfather, shot in 1936, exhume them from the mass grave to which they had been condemned by the Franco regime, and bury them in a cemetery with a plaque commemorating his memory. The use of the term desaparecido from the very title itself illustrates how the figure of the disappeared, an emblematic figure of Latin America and strongly associated with Argentina, has been claimed for the last decade in Spain to refer to the fusilados of Francoism. The transnationalisation of the figure of the disappeared, or the 'desaparecido transnacional' ${ }^{2}$ is an illustrative process of the transnational exchanges, crossroads, decontextualisations and recontextualisations that are characteristic of transnational memory; likewise, of a debate marked by ambiguity, which the title condenses in an exemplary manner. What does the term 'also' mean in "My grandfather was "also" a desaparecido'? Does it mean that Silva's grandfather is 
one more to be added to the thousands of Latin American desaparecidos, or to the lesser known cases of disappearance in Algeria, Chechnya, Lebanon or Sri Lanka? Or does it mean that, in addition to paseado or fusilado or 'victim of Francoist repression', Emilio Silva's grandfather can be thought of according to other categories, including that of the disappeared?

There is no doubt today that the term disappeared has successfully been transported into the Spanish debate on memory. Francisco Ferrándiz states in 'El descubrimiento de las desapariciones forzadas en la España contemporánea':

Beyond political to-ing and fro-ing, academic debates, legal blockages and media bulimia, the figure of forced disappearance has triumphed within the country's imaginary as a new symbolic anchor for the fusilados or paseados who were victims of the troops raised and Franco's dictatorship. ${ }^{3}$

Ferrándiz's words are corroborated by Gabriel Gatti, albeit with a more ironic twist. He states, referring to the exhibition 'Desaparecidos' by Spanish photographer Gervasio Sánchez, which exhibits relatives from different parts of the world holding photos of 'their' desaparecidos: 'The detenido-desaparecido [detained-disappeared] has become transnationalised and today, forty years on, very different and remote situations are thought of with one common patron in mind; one supplied by the figure of the desaparecido in his or her Argentine variant' (Ref. 2, p. 214).

Although the term has been invoked by the movement for the recovery the historical memory in Spain since 2000, it was certainly Judge Baltasar Garzón's decree on 16 October 2008, along with the media controversy that was stirred up around it, that was the turning point in the perception of the repressive legacy of Francoism. In this decree, Judge Garzón considered that during the Civil War and the Franco regime serious violations of rights had taken place, comparable to the legal category of crimes against humanity. He also maintained that the procedure of enforced disappearance was systematically used in Spain to hinder the identification of victims and prevent justice until today. Javier Zaragoza, the Chief Prosecutor of the High Court, filed an appeal dismissing the legal classification of Garzón. Zaragoza harshly questioned that 70 years after the events, Garzón typified every disappearance, turning to 'the fiction of considering him alive and illegally detained until the body appeared, with the object of forcing the absence of prescription of possible pending criminal responsibilities' (quoted in Ref. 3, p. 168).

Nevertheless, the legal debate surrounding the definition of 'disappeared' in the Spanish context is only one aspect of the debate. This new name had consequences far beyond the strict legal framework, producing political, social and symbolic effects that gave new visibility to the victims of Francoism as they 'became part of a much broader category, transnationalised and legally sanctioned by international criminal law in the context of crimes against humanity' (Ref. 3, p. 171). Francisco Ferrándiz, in his exhaustive analysis of the emergence and popularisation of the figure of the disappeared applied to the Spanish case, frames this process in the transnational juridical field. He uses the term 'legal download' to describe what Garzón did, by taking a concept from international criminal law and translating it to a new national 
or local context. It is interesting to analyse the discomfort, embarrassment, or even anger that this 'translation' produced in some people, while for others it was not only plausible, but for many reasons an act to celebrate. Critics pointed out that the use was inaccurate, if not simply a delirium. Historian Julian Casanova, for example, saw the category as confusing, arguing that it should only be applied to 'clandestine' victims in the early months of the war, while the documented and registered fusilados, even if they were loaded with 'anomalies and distortions' corresponded to other kinds of victims. Javier Pradera, meanwhile, rejected the qualification as 'volcado inexacto y engañoso de la experiencia del Cono Sur'. On the other hand, defenders of the translation to the Spanish context strive to demonstrate that the experiences of the Argentine dictatorship and Civil War/Francoism are not as distant as they seem at a first glance. Ferrándiz argues that the term disappeared, 'far from being a neologism inherited from the experience of the Southern Cone dictatorships and International Human Rights Law, and implemented in Spain in a decontextualised manner, does not lack antecedents in the country, even when referring to the Civil War itself' (Ref. 3, p. 169). Furthermore, Ferrándiz intensifies similarities between the two cases. Epistemological uncertainty is one of the hallmarks of disappearance - not knowing what happened, if the person is dead or alive, the exact whereabouts of the body. This feature also dominates the Spanish case: the sacas, paseos and mass graves implemented throughout the country had the same purpose of spreading terror. Finally, the silence of the long period that follows, including not only the Franco dictatorship but also the democratic transition, acts as a 'disappearing factor'. 4 Throughout the article, Ferrándiz explains several times: 'It is clear that the disappeared from the Southern Cone are not equivalent to the fusilados of Francoism'. He insists on his caution, warning of the need not to obscure the differences, but nevertheless claims the category as an indispensable tool for the political demands of the victims. Disappearance seems to be a category that helps to renegotiate the Francoist past.

The concept of memory at stake here reminds us of the conceptualisation proposed by Michael Rothberg in his book Multidirectional Memory. Remembering the Holocaust in the Age of Decolonization (2009). For those supporting the use of the term disappeared applied to Francoism, memory appears as 'multidirectional': 'as subject to ongoing negotiation, cross-referencing, and borrowing; as productive and not privative'. ${ }^{5}$ Memory of Francoism can be productively reactivated and illuminated through reference to other memory; a memory of a different group that is not stated as identical, but analogous. In the context of this debate, it is also interesting to ask to what extent memories are owned by - that is to say, the 'property' of - groups. When referring to the disappeared in this debate, the figure is almost without exception identified as emblematic of the Southern Cone; more precisely, of Argentina. In what sense can the disappeared be claimed as the 'property' of Argentine memory?

In her study about the disappeared in the Argentine press, Estela Schindel ${ }^{6}$ tracks the history of the figure. She finds a first precedent in the 'Nacht und Nebel' (Night and Fog) decree (1941) addressed to the resistance in the countries occupied by the 
Nazi regime. During the Cold War, the 'Counter-insurgency Doctrine' provided the conceptual frame for the application of the enforced disappearance by the French army in Algeria and Indochina, while the Doctrina de Seguridad Nacional (National Security Doctrine) did the same in Latin America, from Guatemala in the 1960s to almost the whole continent in the following decades. These precedents are put aside when a comparison is established only between Spain and Argentina.

It is certain that the sustained act of denunciation of the Argentine Human Rights movement made the enforced disappearance visible worldwide. Even if the impulse to create international legal instances against this repressive practice came from Human Rights organisations all over Latin America, the figure of the desaparecido has remained identified since the 1970s with the Argentine case. Gabriel Gatti refers to this when he affirms that 'the Argentinean definition of the disappeared and enforced disappearance has become law' (Ref. 2, p. 219). It is perhaps the manner in which Argentina was effectively able to name and define the traits of the desaparecido that provides one of the explanations of the emphasis given by Spanish academic literature to the analogies and differences with the Southern Cone and particularly with Argentina. The trials instigated by Garzón against Augusto Pinochet, Adolfo Scilingo and other Argentine military men, contributed to the visibility of South American disappearances to the detriment of other disappearances in other parts of the world. Enforced disappearance as a repressive technique is neither exclusive to the past nor a specific continent and has been appropriated as a frame of reference and legal tool by human rights organisations from different countries. In fact, the Asociación para la Recuperación de la Memoria Histórica de Cataluña is part of the FEMED (Fédération Euro-méditerranéenne contre les Disparitions Forcées), along with organisations in Algeria, Cyprus, Morocco, Turkey, and so on; nevertheless, the similarities with these disappearances are never problematised in the debate to which we refer here.

We could formulate the hypothesis that Argentina not only popularised the term, but also provided the figure with a set of concrete and recognisable images and narratives of resistance that have the capacity to condense and awaken a particular emotion. When Emilio Silva uses the term desaparecido, this term describes not so much the status of his grandfather as a victim, but rather himself. It refers to his own anguish, to the psychological effect produced by disappearance on the lives of the relatives. In this sense, it is less important if uncertainty about the whereabouts and the consequent difficulty in mourning respond to a systematic repressive practice, as in the case of Argentina, or the more chaotic and semi-public repressive practices of the Spanish retaguardia. What you 'download' here is not a specific concept, but a 'content' that summons a subjective experience that primarily affects the families of the victims and serves as a condensation of that experience: the silence, the uncertainty, the impunity.

Thus, disappearance sheds light on how parents, children or grandchildren have experienced the Franco regime, the way their psychological lives have been affected by the uncertainty of not knowing the exact circumstances of the death of their relatives, the final whereabouts of their remains and the consequent difficulty grieving 
and honouring his or her memory. It also opens up the possibility that this experience might be shared, leading to the formation of a community and facilitating the construction of a collective identity that acts against the stigmatisation and isolation to which these families were subject under Franco. It is no accident, in this sense, that in the article Silva concludes by invoking the burial of the remains as a closure of a cycle, and a shared experience with another victim:

Since the day on which the commemorative plaque was hung, history has been that little bit more just. The path has not been too long. The remains of Emilio Silva Faba, Enrique González Miguel and another eleven men can rest in the place chosen by their families. [...] 'So many years and so few in the heart', as Belia, the daughter of Enrique González, said to me on the day on which her father ceased to be a desaparecido. (Ref. 1, p. 1.)

The analogies between distant experiences, then, take on a different meaning as what is translated is a subjective experience and this comparison works on the identification of a common affection. Beyond the political and social contexts, which are as diverse as Guatemala, Argentina or Spain, disappearance has a common feature that is located in how uncertainty affects the mental life of those who experience the loss: absence becomes a totalising force that gradually empties the world of its solidity and consistency. The disappearance acquires a pervasive quality that haunts the present with remnants of the past. 'Drawn into the vortex of haunting memories, the here and now vanishes affective and temporarily loses its hold on me. Ghosts seem to win the competition with the living, ${ }^{7}$ as described by Gabriele Schwab.

It is this affection that can be translated, the common recognition that we have been equally affected. At this point, the term 'disappeared' establishes a fundamental difference with the fusilado or paseado. The disappearance introduces another temporality, which dissolves the distance between past and present. And through the appropriation of content, a precise figure summons a particular affection, on the basis of which practices of resistance can be created. 'Transnational memory' works, in this case, by creating transnational communities linked through a particular affection.

In the discussion above, the figure of the disappeared, identified with the dictatorships of the Southern Cone, is appropriated by a distant context with a precise political goal: to give visibility to Franco's victims, contributing to reopen the occluded debate. The disappeared are recognisable in a set of images and narratives. But, does a transnational memory of disappearance - in the Hispanic context always work this way? Can the disappeared be transported to the Spanish context with other uses, other goals?

In 'Travelling memory' (2011) Astrid Erll distinguishes between five dimensions of movement: ${ }^{8}$ carriers, media, contents, practices and forms. In the public debate, media took a central role in circulating the experience of the Argentine disappearance as 'content'; that is, shared images and narratives, images (as in the case of the photographic exhibition) or narratives (bearing the affective characteristic of disappearance) that give the figure of the disappeared a clear outline, a precise meaning. 
Through a process of analogy, this figure can be 'applied' to a different context, and the fusilados or paseados from Spain can now be reinterpreted.

While 'content' refers to a precise set of images and narratives that give memory a precise meaning, the dimension of 'form' refers to quite the opposite: the movement of condensation and 'diffumination' that a memory can experience.

We would like to take this concept to see how disappearance is appropriated in the Spanish context in a different way than the aforementioned public debate. What happens when disappearance is appropriated as a literary figure?

In 2004, a young Spanish writer, Isaac Rosa, published El vano ayer (Vain Yesterday), a novel that quickly gained the recognition of critics, being awarded in 2005 one of the most important Hispano-American prizes, the Rómulo Gallegos International Novel Prize.

The novel deals with the memory of the Franco regime. From the very beginning, it refuses to construct 'another novel' on the Dictatorship. The novel, following modernist techniques, is a highly reflexive narrative in which the author constantly discusses the construction of the characters, the progression of the plot and the stereotypes used in previous novels to portray the Civil War. It warns about the 'banalisation' and trivialisation of History, about use of the Civil War and the Franco regime as an innocent background for a story that ends up constructing a nostalgic or a farcical portrait of the past. On the contrary, the novel wishes to tell the story in a way that can question the reader and especially, the reader's present.

At the beginning, the author wonders ironically about what would be the best 'anecdote' to write the book, and after searching the archives of old books on the Civil War, he chooses an obscure episode about a professor exiled by the Franco regime, that appears in La Universidad española bajo el regimen de Franco (1939-1975), by Juan José Carreras Ares and Miguel Ángel Ruiz Carnicer. The professor, called Julio Denis, appears as an ambiguous figure and remains as such throughout the text. The plot juxtaposes different possibilities: was the professor as he appears to be, ideologically 'neutral' - neither related to the Franco regime nor committed in his opposition to Franco - and his detention a merely incidental? Was he, on the contrary, a chivato (snitch)? Or was he secretly involved with the Resistance? His exile is apparently related to the detention of a student called André Sánchez, with whom the professor had had an appointment the day prior to which both were detained. What appears as striking, however, in the context of a novel on the Civil War is that both the professor, Julio Denis, and the student are portrayed and named as disappeared. The case of the student could be easily identified as enforced disappearance: the victim was involved in the Resistance, nobody knows what happened to him after the illegal detention, if he was murdered or not. The traces are left in shadows. Although the testimonies allow us to think that he was murdered in jail, there is uncertainty about the remains and the location of his body. In the case of the professor, his 'disappearance' has a different nature: the reader knows that he left the jail alive and is exiled to France, but again, the traces of his life become lost after the episode. The duplication of the shadows in both characters puts disappearance at the centre of the novel, a centralisation that makes us think again in 
the appropriation of a figure foreign to the Spanish context at that time, a kind of anachronism. Disappearance, as a repressive method, is not characteristic of Franco's police force in the 1960s, but an exceptional case. Another trail makes us relate the experience of the Franco Regime with Argentina; indirectly the figure of the professor recalls one of the most famous Argentine writers, Julio Cortázar. Julio Denis, the name chosen by Rosa, is the pseudonym that Cortázar used to sign his first book of poems, entitled Presencia (Presence, 1938). There are also historical and cultural links between Spain and Latin America that naturally bring this story closer to the Argentine experience.

However, if the political character of the disappearance of Sánchez refers the reader to the Latin American context and disappearance as typified by the 'International Convention for the Protection of All Persons from Enforced Disappearance', that of professor Julio Denis prevents the direct appropriation of this figure. Denis disappears in Paris, depressed, penniless and the only person who knows him looks for him among the clochards. It seems not to be an enforced disappearance. Besides, one of the last parts of the book talks about the diverse ways in which a person can disappear, and alongside the clandestine assassinations, the narrator mentions the case of people who leave to live an apocryphal life elsewhere. While Sánchez is 'disappeared', Denis is missing. The difference between 'disappeared' and 'missing' is a difference for which the Spanish language cannot account.

As Raquel Maciucci puts it:

Disappearance in the novel becomes a metaphor for absence. [...] Absence is the story's centre of gravity; the symbolic nucleus which, on the level of composition, upholds the intention of building a memory that is both critical and unsettling [...]. The figure of the desaparecido imposes itself above that of the deceased in police stations and above the alienation of the exile in a manner in which the author achieves one of the most disturbing, and at the same time, refractory effects upon any kind of reassuring dénouement, for can there be a figure more capable of denying closure than that of the desaparecido?

If disappearance in El vano ayer is a figure of indeterminacy, the novel, as it deconstructs all the narrative mechanisms that it itself proposes, also erodes the figure of the disappeared, via its references to other kinds of disappearance that are not directly political.

In a similar vein, Alejandro Moreira highlights the disruptive effects that the figure of the disappeared produces on closing narratives. 'Linked in principle to a situation of oppression and silence, it has functioned as an active figure who, far from sealing the past, provokes its emergence in the present and moves towards the future as a promise of justice'. ${ }^{10}$ A similar function is fulfilled here: the phenomenon of disappearance is an uncertainty that resists closure of the narrative and, consequently, closure of the senses of the past. It allows the past to be projected into the present, and in fact, the final testimonies of the novel reach the reader's own present.

The figure of disappearance functions in El vano ayer in a different way than in the cases foregrounded in the previous debate. Explicit reference was made in the debate 
to the disappeared of the Southern Cone and, in some cases (as in the photographic exhibition, for example), to the use of identical strategies to explicitly relate to both contexts. In the novel, on the contrary, there is no clear link between the two. The gesture of 'appropriation' of a foreign figure is absent, because acknowledgment of the disappeared with traits characteristic of the Argentine experience is not alluded to in the novel.

For example, El vano ayer deprives both characters of the relatives that are one of the supports of the Argentine figure: from the very beginning, the desaparecidos were first and foremost sons/daughters (of the Madres de Plaza de Mayo), and grandchildren (the babies searched by the Abuelas de Plaza de Mayo). They were also, albeit to a lesser extent, brothers, sisters and spouses. The brief episode in which the grandmother of André Sánchez looks for him in the jails is the only passage that recovers this element of that figure, and, by contrast, it highlights Rosa's choice to avoid stereotypes.

There is, therefore, no linear appropriation and adoption. Disappearance in $E l$ vano ayer becomes a figure that is much more diffuse; a sort of symbolic emptiness capable of evoking the materiality of absence. In this sense, we could state that 'what' travels is different if we look at the public debate or at the realm of literature in the Spanish case. The 'memory' of literature works by opening up meanings, multiplying the layers of significance. What is furthermore striking is that in the case of El vano ayer, the novel refuses any kind of affectivity, and in particular, the affectivity related to disappearance. The disappearance in El vano ayer becomes not 'content', but rather a 'form', in Erll's terms:

Mnemonic forms are the condensed Figures (symbols, icons or schemata) of remembering that enable repetition and are often themselves powerful carriers of meaning. In fact, much of travelling memory is first of all enabled through the condensation of complex and confusing traces of the past into succinct mnemonic forms. [...] In their displacement memory figures tend to be stripped of their complexity, detached from the details and contextual meanings they originally referred to. This can lead to distortion, even perversion, of memories. But Andres Huyssen also emphasizes the enabling potential of such 'floating signifiers'. (Ref. 8, p. 14)

Could 'disappearance' be finally thought of as a kind of regional, HispanoAmerican 'floating signifier', in the sense that Daniel Levy and Natan Sznaider speak of the Holocaust as a 'cosmopolitan' symbol? ${ }^{11}$ Isaac Rosa's speech when accepting the Rómulo Gallegos prize seems to verify this hypothesis. The author does not directly relate his use of the term 'disappeared' with the history of Latin America. Instead, he reads the prize in terms of his novel's resonance in Latin America, rather than the inverse:

That a novel such as this can receive the Rómulo Gallegos Prize, granted by a jury on which no Spaniard sits, is confirmation of the fact that it can be read beyond what is local and Spanish. Hence, I said that it is not so much, or at least not only, a novel about Francoism. I believe that it can be read clearly in this continent, amongst Latin American countries [...]. Many of the reflections suggested in Vain Yesterday are certainly valid in many of these countries. Only a few adjustments - changes of name, date - are required, little more than that. ${ }^{12}$ 
'Disappearance' is finally a figure marked by the non-place: the impossibility of assigning a place to his or her tomb, to his or her body, is the mark that differentiates it from other types of victim. With transatlantic exchanges, this non-place seems to change its meaning: the non-place seems now not to be a condemnation, but the possibility of new transnational communities in the Hispanic world.

\section{Acknowledgements}

The research leading to this article has received funding from the European Research Council under the European Union's Seventh Framework Programme (FP/20072013) ERC Grant Agreement no. 240984, 'NOT'.

\section{References and Notes}

1. E. Barrera Silva (2000) Mi abuelo también fue un desaparecido. Crónica de León, October 8.

2. G. Gatti (2011) Identidades desaparecidas. Peleas por el sentido en los mundos de la desaparición forzada (Buenos Aires: Prometeo).

3. F. Ferrándiz (2010) De las fosas comunes a los derechos humanos: El descubrimiento de las desapariciones forzadas en la España Contemporánea. Revista de Antropología Social, 19, p. 176. All translations are our own.

4. P. Calveiro (1998) Poder y desaparición: los campos de concentración en Argentina (Buenos Aires: Colihue).

5. M. Rothberg (2009) Multidirectional Memory: Remembering the Holocaust in the Age of Decolonization (Stanford: Stanford University Press), p. 3.

6. E. Schindel (2012) La desaparición a diario. Sociedad, prensa y dictadura (1975-1978) (Eduvim: Villa María), pp. 37-39.

7. G. Schwab (2013) Unofficial wars: the politics of disappearance. Universität Konstanz. Lecture, p. 3.

8. A. Erll (2011) Travelling memory. Parallax, 17(4).

9. R. Macciuci (2010) El pasado sin red. Poética y moral de la memoria en El vano ayer de Isaac Rosa. In: R. Macciuci, Raquel and M. T. Pochat (eds), Entre la memoria propia y la ajena. Tendencias y debates en la narrativa española actual (La Plata: Ediciones del lado de acá), p. 251.

10. A. Moreira (2009) La historia perdida. Lecturas de los años setenta en la Argentina contemporánea. Boletín Hispánico Helvético, 13-14, p. 9.

11. D. Levy and N. Sznaider (2002) Memory unbound: the holocaust and the formation of cosmopolitan memory. European Journal of Social Theory, 5(1), pp. $87-106$.

12. Isaac Rosa Premio Internacional Rómulo Gallegos Discurso de agradecimiento, http://www.analitica.com/va/arte/documentos/9269062.asp (accessed 10 September 2013).

\section{About the Authors}

Silvana Mandolessi is a Postdoctoral Fellow of the European Research Council at the Universität Konstanz and Assistant Professor at the K.U. Leuven. She is author of Una literatura abyecta. Gombrowicz en la tradición argentina (2012) and co-editor of El juego con los estereotipos. La redefinición de la identidad hispánica en la literatura y el cine posnacionales (2012). 
Mariana Eva Perez is a Doctoral Fellow of the European Research Council at the Universität Konstanz. She is a playwright and novelist and has published numerous academic articles on memory and theatre. She is also author of Diario de una princesa montonera (2012). 